\title{
MENINGKATKAN KEMAMPUAN MEMBACA PEMAHAMAN PADA ANAK TUNARUNGU LEWAT MEDIA GAMBAR
}

\author{
Erna Juherna ${ }^{1}$, Adinda Farwati Putri ${ }^{2}$, Euis Sugihartini ${ }^{3}$, Feby Valentina ${ }^{4}$, Lilim Halimatul Mutmainah ${ }^{5}$, \\ Vindri Ramadhaniati ${ }^{6}$ \\ Email: erna@upmk.ac.id ${ }^{1}$, adindafarwati3@gmail.com² ${ }^{2}$, euis.sugihartini82@gmail.com ${ }^{3}$, \\ febyvale2000@gmail.com ${ }^{4}$, lilimhalimatu194@gmail.com ${ }^{5}$, vindri1999@gmail.com ${ }^{6}$ \\ Juherna, Erna. dkk. (2020). Meningkatkan Kemampuan Membaca Pemahaman pada Anak Tunarungu Lewat Media \\ Gambar. Jurnal Pelita PAUD, 5(2), 256-261. \\ doi: https://doi.org/10.33222/pelitapaud.v5i2.1219
}

Diterima: 04-01-2021

Disetujui: 18-06-2021

Dipublikasikan: 24-06-2021

Abstrak: Penelitian ini bertujuan untuk meningkatkan kemampuan membaca pemahaman pada anak tunarungu lewat media gambar. Metode penelitian ini menggunakan penelitian kuantitatif dengan metode eksperimen dalam bentuk Single Subject Research (SSR). Penelitian ini dilaksanakan di KB Kemuning Kabupaten Kuningan. Pengumpulan dan anaisis data melalui studi pustaka, teknik observasi, dan teknik analisis dengan erbagi menjadi dua yakni pretest, post-test. Berdasarkan hasil penelitian dan analisis pembahasan mengenai Peningkatan kemampuan membaca pemahaman pada anak tunarungu lewat media gambar menunjukkan bahwa anak tunarungu memiliki potensi untuk belajar berbicara dan berbahasa. Salah satu cara berbahasa yang diajarkan untuk anak tuna rungu adalah dengan cara membaca pemahaman lewat media gambar. Hal ini penting dilakukan pada anak tuna rungu untuk berkomunikasi karena anak tuna rungu hanya bisa belajar secara visual. Dengan penelitian belajar menggunakan media bergambar ternyata mampu meningkatkan kemampuan pemahaman anak tunarungu melalui kartu bergambar sebagai kemampuan membaca pemahaman anak tunarungu perlu dilakukan

Kata kunci: Membaca. Tunarungu, Media Gambar

Abstract: This study aims to improve reading comprehension skills in deaf children through image media. This research method uses quantitative research with experimental methods in the form of Single Subject Research (SSR). This research was conducted in KB Kemuning, Kuningan Regency. Collecting and analyzing data through literature study, observation technique, and analysis technique divided into two, namely pretest, post-test. Based on the results of research and analysis of discussions regarding the improvement of reading comprehension skills in deaf children through image media, it shows that deaf children have the potential to learn to speak and speak. One of the ways in which language is taught to deaf children is by reading comprehension through picture media. This is important for deaf children to communicate because deaf children can only learn visually. With research on learning to use illustrated media, it turns out that it is able to improve the understanding ability of deaf children through picture cards as the ability to read understanding of deaf children needs to be done.

Kevwords: Read. Deaf. Picture Media 


\section{PENDAHULUAN}

Dukungan dalam bentuk komitmen konstitusional negara bagi anak berkebutuhan khusus telah dijamin dalam perundangundangan dan kelembagaan pemerintah dalam mendorong peningkatan perlindungan anak tanpa diskriminasi. Berkaitan dengan komitmen tersebut telah diterbitkan Undang- Undang Nomor 19 Tahun 2011, tentang Pengesahan Konvensi Mengenai Hak-hak Penyandang Disabilitas (Convention On The Rigths Of Persons With Disabilities) dan diterbitkanya Peraturan Menteri Negara Pemberdayaan Perempuan dan Perlindungan Anak Nomor 10 Tahun 2011 tentang Kebijakan Penanganan Anak Berkebutuhan Khusus. Kedua peraturan perundangan tersebut merupakan upaya pemerintah untuk memberikan perlindungan dan pelayanan terhadap anak berkebutuhan khusus.

Dalam menangani anak-anak berkebutuhan khusus, para pendamping memerlukan pengetahuan tentang anak-anak tersebut, keterampilan mengasuh dan melayaninya. Anak berkebutuhan khusus perlu mendapat dorongan, tuntunan, dan praktek langsung secara bertahap. Potensi yang dimiliki anak- anak berkebutuhan khusus akan tumbuh berkembang seiring dengan keberhasilan peran pendamping dalam memahami dan memupuk potensi anak-anak tersebut.

Anak tunarungu merupakan anak yang mempunyai gangguan pada pendengarannya sehingga tidak dapat mendengar bunyi dengan sempurna atau bahkan tidak dapat mendengar sama sekali, tetapi dipercayai bahwa tidak ada satupun manusia yang tidak bisa mendengar sama sekali. Walaupun sangat sedikit, masih ada sisa-sisa pendengaran yang masih bisa dioptimalkan pada anak tunarungu tersebut. Berkenaan dengan tunarungu, terutama tentang pengertian tunarungu terdapat beberapa pengertian sesuai dengan pandangan masingmasing.

Ketunarunguan dibedakan menjadi dua kategori, yaitu tuli (deaf) atau kurang dengar (hard of hearing) (Laila, 2013: 10). Anak tunarungu mengalami gangguan pada organ sehingga mengakibatkan ketidakmampuan mendengar, mulai dari tingkatan yang ringan sampai yang berat sekali yang diklasifikasikan kedalam tuli (deaf) dan kurang dengar (hard of hearing). Sugiarto menegaskan bahwa media pembelajaran adalah segala sesuatu yang digunakan orang utnuk menyampaikan pesan pembelajaran. Media pembelajaran yang baik harus memenuhi beberapa syarat, yaitu meningkatkan motivasi dan merangsang siswa untuk belajar, media dapat menjadikan siswa aktif dalam memberikan tanggapan, umpan balik dan mendorong siswa melakukan praktik yang benar (Tatang S, 2015: 54).

Membangun komunikasi dan pendidikan bagi anak berkebutuhan khusus yaitu anak dengan kebutuhan khusus yang memiliki cacat fisik dan juga mentalnya, harusnya anak dengan kebutuhan khusus mendapat semangat dan pendampingan secara khusus dari tenaga pendidik yang mengasuhnya yang tidak hanya pandai mengajar tetapi juga berkomunikasi hati ke hati.

Meskipun secara fisik anak tuna rungu hampir sama dengan anak normal pada umumnya, namun anak tuna rungu mempunyai ciri-ciri yang sering terjadi pada mereka, dalam hal ini, Nur'aeni menyebutkan ciri-ciri tersebut diantaranya, sering tampak bingung dan melamun, sering bersikap tak acuh, kadang bersifat agresif, perkembangan sosialnya terbelakang, keseimbangannya kurang, kepalanya sering miring, sering meminta agar orang mau mengulang kalimatnya, jika bicara sering membuat suara-suara tertentu, jika bicara sering menggunakan juga tangan, jika bicara sering terlalu keras atau sebaliknya, sering sangat monoton, tidak tepat dan kadang-kadang menggunakan suara hidung (Nur'aeni 1997). Strategi pembelajaran yang biasa digunakan untuk anak tunarungu antara lain: strategi deduktif, induktif, heuristic, ekspositorik, klasikal, kelompok, individual, kooperatif, dan modifikasi perilaku. Dengan adanya pelaksanaan suatu prinsip pada anak berkebutuhan khusus (tunarungu), perlu didukung oleh pengembangan kurikulum atau pembelajaran diantaranya pengembangan karakter karena dapat menjadi suatu sarana yang efektif dalam penanaman nilai-nilai karakter. (Hamid Muhammad 2014)

Dampak langsung dari ketunarunguan adalah terhambatnya komunikasi verbal/lisan, baik secara ekspresif (berbicara) maupun reseptif (memahami pembicaraan orang lain), sehingga sulit berkomunikasi dengan lingkungan, orang 
mendengar yang lazim menggunakan bahasa verbal sebagai alat komunikasi. Hambatan dalam berkomunikasi tersebut, berakibat juga pada hambatan dalam proses pendidikan dan pembelajaran anak tunarungu.

Komunikasi Interpersonal sangat dominan dilakukan pada anak disabilitas dimana terjadi interaksi antara dua orang atau lebih secara langsung. Komunikasi ini sangat tepat untuk melihat dan mempengaruhi sikap, pendapat, atau perilaku seseorang. Komunikasi interpersonal bersifat timbal balik berhasil atau tidak, jika tidak berhasil maka komunikator bisa mempersilahkkan komunikan untuk bertanya dan bicara sejauh pemahamannya. Sangat berbeda pada anak disabilitas tunarungu wicara sebab adanya kelainan pada alat pendengaran dan organ bicaranya menyebabkan permasalahan untuk berkomunikasi.

Intelegensi anak tunarungu tidak berbeda dengan anak normal yaitu tinggi, rata-rata dan rendah. Pada umumnya anak tunarungu memiliki intelegensi normal dan rata-rata. Prestasi anak tunarungu seringkali lebih rendah daripada prestasi anak normal karena dipengaruhi oleh kemampuan anak tunarungu dalam mengerti pelajaran yang diverbalkan. Namun untuk pelajaran yang tidak diverbalkan, anak tunarungu memiliki perkembangan yang sama cepatnya dengan anak normal. Prestasi anak tunarungu yang rendah bukan disebabkan karena intelegensinya rendah namun karena anak tunarungu tidak dapat memaksimalkan intelegensi yang dimiliki. Aspek intelegensi yang bersumber pada verbal seringkali rendah, namun aspek intelegensi yang bersumber pada penglihatan dan motorik akan berkembang dengan cepat.

Anak tunarungu akan cepat memahami hal yang pernah dialaminya, sehingga variasi pengalamannya juga sangat mempengaruhi perkembangan kognitifnya. Lingkungan yang berbahasa intensif akan lebih baik untuk perkembangan kognitif anak

tunarungu, karena jika dibiasakan berbahasa walaupun sebelumnya tidak memahami apa yang dikatakan, anak tunarungu akan menjadi lebih kaya akan bahasa sehingga membantu perkembangan kognitifnya. Tingkat kecacatan dan ada tidaknya kecacatan lain mempengaruhi kemampuan anak tunarungu dalam beradaptasi dengan lingkungan. Jika pada anak tunarungu ringan, pembelajaran dapat dibantu dengan dipergunakannya alat bantu dengar, tidak demikian dengan anak tunarungu yang berat. Jika anak tunarungu memiliki kecacatan lain, maka akan berpengaruh pada adaptasi perilaku lain yang dapat memperlambat kemampuan kognitifnya,

bahkan lebih kompleks dari itu.

\section{METODE PENELITIAN \\ Jenis Penelitian}

Jenis penelitian yang digunakan yaitu metode eksperimen, dapat diartikan sebagai pendekatan penelitian kuantitatif yang yang paling penuh, dalam arti memenuhi semua persyaratan untuk menguji hubungan sebab-akibat dengan maksud untuk melihat akibat dari suatu perlakuan. (Sukmadinata, 2017: 95). Dengan metode Eksperimen merupakan kegiatan percobaan untuk meneliti suatu peristiwa atau gejala yang muncul pada kondisi tertentu. Memberi batasan "metode penelitian eksperimen merupakan metode penelitian yang digunakan untuk mencari pengaruh treatment (perlakuan tertentu)". Penelitian bersifat eksperimen ini memiliki subjek tunggal dengan pendekatan single subject researth (SSR), yaitu eksperimen yang dilaksanakan pada satu objek pada tujuan untuk mencari pengaruh perlakuan tertentu terhadap yang lain dalam kondisi yang terkendalikan (Sugiyono 2015: 107)

\section{Waktu dan Tempat Penelitian}

Penelitian ini dilakukan pada tanggal 27 Desember sampai dengan tanggal 30 Desember 2020 yang dilakukan di rumah anak tuna rungudi $\mathrm{KB}$ Kemuning Kabupaten Kuningan Jawa Barat.

\section{Subjek Penelitian}

Subjek dalam penelitian ini adalah anak tuna rungu dengan rentang usia 6 tahun yang dilakukan dengan memberikan intervensi terhadap anak tunarungu, kemudian melakukan wawancara dengan Orang Tua anak, terkait bagaimana metode yang dilakukan di rumah untuk menyelaraskan metode yang diberikan di sekolah kemudian mengobservasi keefektifan metode tersebut.

\section{Prosedur}

Prosedur dalam penelitian ini dilakukan dengan berbagai tahapan seperti halnya dengan tahap 
persiapan Tahap persiapan, perancangan eksperimen dengan desain desain praeksperimen menerapkan perlakuan kepada subjek penelitian tanpa adanya kelompok kontrol (bandingan yang tidak diberi perlakuan). Selain itu, pra-eksperimen proses penelitiannya fokus pada dampak perubahan dari perlakuan subjek penelitian yang diamati (Indrawan, 2016: 57).

\section{Data, Intrumen, dan Teknik Pengumpulan Data}

Data yang dikumpulkan dalam penelitian ini yaitu dengan pengumpulan data melalui studi pustaka, merupakan proses menelaah bukubuku untuk memperoleh informasi mengenai materi serta teori-teori yang relevan dan berhubungan dengan pembelajaran. Adapun buku-buku yang penulis telaah adalah buku tentang keterampilan membaca, buku tentang teks laporan hasil observasi, dan buku tentang model contexstual teaching learning.

Teknik observasi digunakan untuk mengetahui keadaan atau kondisi yang akan dijadikan tempat penelitian. Tes Dalam penelitian ini penulis melakukan tes, berupa pretes dan postes dengan bentuk tes berupa soal. Teknik ini dilakukan untuk mengetahui kemampuan peserta didik. Analisis, menggunakan teknik analisis dengan cara menguji data yang terkumpul. Hal ini dilakukan dengan memperoleh hasil yang akurat dan digunakan untuk menganalisis kesulitan yang dihadapi oleh peserta didik dalam menginterpretasi isi teks laporan hasil observasi berdasarkan interpretasi.

Instumen penelitian merupakan alat yang digunakan penulis untuk mengumpulkan Arikunto (2015: 203) mengungkapkan, "Instrumen penelitian adalah alat fasilitas yang digunakan oleh peneliti dalam mengumpulkan data agar pekerjaannya lebih mudah dan hasilnya lebih baik, dalam arti lebih cepat lengkap, dan sistematis sehingga lebih mudah diolah".

\section{Teknik Analisis Data}

Teknik analisis data dimulai pada dengan mengelompokkan data kemudian mentabulasikan atau menyajikan data dalam bentuk tabel, untuk memudahkan pengamatan atau evaluasi. Selanjutnya melakukan perhitungan untuk menjawan rumusan masalah, dan melakukan perhitungan untuk menguji hipotesis (Sugiyono, 2015: 207).

Pelaksanaan penelitian tahap eksperimen ini akan terbagi menjadi dua, yakni a) Pretest yang melakukan suatu hal tanpa diberi perlakuan atau disebut dengan studi kontrol; b) Post-test, yakni melakukan suatu hal dengan diberi perlakuan sesuai dengan rancangan eksperimen.

\section{HASIL PENELITIAN DAN PEMBAHASAN}

Pemerolehan bahasa pertama anak tunarungu dapat dilakukan dengan komunikasi total. Komunikasi total merupakan sistem komunikasi paling efektif karena selain menggunakan bentuk komunikasi secara lisan atau disebut oral, dengan kegiatan membaca, menulis, membaca ujaran, juga dilengkapi dengan bentuk isyarat. Isyarat layaknya bahasa alami untuk tunarungu, walaupun bentuknya berbeda di beberapa daerah namun ada sistem isyarat bahasa indonesia yang dibakukan. Pemerolehan bahasa anak tunarungu yaitu memahami ujaran melalui media membaca ujaran. Membaca ujaran merupakan unsur atau dasar sistem bahasa batinnya.

Anak tunarungu terdiri dari kata-kata sebagaimana tampil pada gerak dan corak sebagai pengganti bunyi bahasa yang berupa vokal, konsonan, dan intonasi pada anak mendengar. Sama seperti keadaan anak mendengar, pada anak tunarungu kemampuan bahasa ekspresif (bicara) baru dapat dituntut setelah terjadi perkembangan bahasa reseptif. Pengalaman atau situasi bersama dengan orang tua (ibunya) merupakan persyaratan pertama. Dapat dikatakan bahwa masukan bahasa dalam jumlah besar merupakan suatu syarat sebelum anak tunarungu dituntut mengekspesikan diri melalui bicara. Hal ini kiranya akan menjadi jelas bahwa untuk mengatasi permasalahan yang mungkin timbul bagi para orang dengan kecacatan rungu wicara atau tunarungu adalah diberikannya pelayanan khusus yang mampu mengembangkan pemerolehan bahasa dan kemampuan berbahasa yang sesuai dengan kondisinya.

Pemerolehan bahasa adalah proses yang berlangsung di dalam otak seseorang ketika memperoleh bahasa pertamanya atau bahasa ibunya. Jadi, pemerolehan bahasa berkenaan dengan bahasa pertama. (Kuntarto, 2017). 
Komunikasi total adalah salah satu pandangan atau konsep komunikasi bagi orang dengan kecacatan rungu wicara, yang bertujuan mencapai komunikasi yang efektif antara sesama orang dengan kecacatan rungu wicara ataupun orang dengan kecacatan rungu wicara dengan masyarakat luas dengan menggunakan media berbicara, membaca bibir, mendengar, dan berisyarat secara terpadu. Komunikasi total bukanlah suatu metode pengajaran cara komunikasi, melainkan dapat diumpamakan sebagai tujuan pendidikan untuk mencapai kemampuan berkomunikasi dengan yang baik. (Noviantari, 2010).

Kemampuan membaca pemahaman anak tunarungu dipengaruhi oleh keterbatasannya dalam menerima informasi, menyimpan informasi, dan mengungkapkan informasi tersebut sebagai sebuah pemahaman dalam proses yang disebut dengan proses kognitif. Hal-hal yang mempengaruhi perkembangan kognitif diatas dapat dihubungkan dengan kemampuan anak tunarungu dalam berkomunikasi secara keseluruhan. Tingkat kemampuan bahasa sudah sangat jelas mempengaruhi kemampuan kognitif seseorang, karena kemampuan kognitif dapat berkembang dengan cara berkomunikasi dan mengelola informasi yang didapatkan dari lingkungan. Anak tunarungu kesulitan dalam mendapatkan informasi selain dari penglihatannya, sehingga kemampuan berbahasa anak tunarungu relatif rendah daripada anak normal.

Menurut Gunaman (2016), Menjelaskan komtal (Komunikasi Total) adalah pendekatan dalam pendidikan bagi kaum tunarungu yang menganjurkan penggunaan berbagai bentuk media komunikasi untuk meningkatkan keterampilan berbahasa. Komtal adalah falsafah yang mencakup cara komunikasi aural, manual dan oral sehingga terjadi komunikasi yang efektif dengan dan diantara kaum tunarungu.

Penelitian di lakukan selama 4 kali pertemuan, pada pertemuan pertama peneliti ingin mengetahui metode apa yang digunakan disekolah dan d rumah untuk meningkatkan kemampuan membaca anak melalui wawancara kepada guru dan orangtua nya serta melihat secara langsung kondisi anak.

Pada hari ke dua peneliti mencoba berinteraksi langsung terhadap anak tersebut dengan memberikan sebuah kartu bergambar. Gambar yang diberikan adalah gambar yang sederhana seperti gambar macam-macam hewan, benda, dan tanaman.

Pada hari ke tiga Peneliti mencoba memberikan kartu yang bergambar kegiatan aktivitas seharihari seperti mandi dan makan serta peneliti memberikan gambar-gambar yang berisi tentang cerita seperti gambar cerita si kancil dan gambar super hero kesukaan anak tersebut.. Dalam memberikan pemahaman melalui gambar peneliti mencoba menjelaskan isi gambar tersebut dengan menggunakan ucapan kata dan gerakan mulut yang jelas sambil memberikan gerakan isyarat untuk memberikan pemahaman tentang isi gambar tersebut.

Pada hari terakhir, peneliti mencoba menanyakan tentang gambar-gambar yang sudah di sampaikan pada hari sebelumnya dengan maksud mengetahui sejauh mana anak ini dapat menangkap segala informasi dan mengetahui maksud dari gambar-gambar yang sudah di sampaikan sebelumnya. Dan ternyata respon anak ini meningkat, dia sudah bisa paham gambar yang peneliti berikan dan mengungkapkan pemahamannya dengan bahasa isyarat seperti gambar jerapah, anak dapat memberikan gerakan tangan seperti jerapah yang lehernya panjang.

Disamping peneliti memberikan pemahaman melalui gambar, penelitipun berkoordinasi dengan orang tua agar perlakuan yang di berikan di sekolah dapat berjalan selaras dengan perlakuan di rumah, karena kerjasama yang baik antara orang tua dan juga lembaga dapat mencapai tujuan yang diinginkan.

Intervensi terhadap kemampuan membaca pemahaman anak tunarungu perlu dilakukan melalui pelaksanaan pembelajaran membaca dengan metode yang tepat agar pemrosesan informasi dapat berjalan dengan baik. Berdasarkan karakteristik anak tunarungu yang lebih dapat berkonsentrasi pada hal yang konkret dan pengalaman pribadinya, maka pembelajaran membaca pemahaman pada anak tunarungu harus memperhatikan hal tersebut.

\section{SIMPULAN}

Tunarungu adalah suatu kondisi atau keadaan dimana seseorang mengalami kekurangan atau kehilangan indera pendengaran sehingga tidak 
mampu menangkap stimulus berupa bunyi, suara atau stimulus hal lain melalui pendengaran. Akibat dari terhambatnya perkembangan terhadap pendengarannya pun seorang tunarungu sangat berpengaruh terhadap perkembangan lainnya seperti pada kemampuan bicara dan bahasanya, yang mengakibatkan seorang tunarungu akan mengalami kelambatan dan kesulitan dalam hal-hal yang berhubungan dengan komunikasi.

Berdasarkan hasil penelitian belajar menggunakan media bergambar ternyata mampu meningkatkan kemampuan pemahaman anak tunarungu dalam membaca. Hal ini merupakan suatu intervensi yang baik dan perlu dilakukan melalui pelaksanaan pembelajaran membaca dengan metode yang tepat. Karena dengan adanya penggunaan media gambar dapat memotivasi siswa dalam memahami pembelajaran membaca dengan benar. Memiliki perkembangan signifikan dalam pembelajarannya.

Penggunaan media gambar memberikan dampak positif terhadap sikap siswa, Secara kualitatif kinerja guru akan menjadi optimal dan lebih baik serta terampil untuk mengembangkan suatu keterampilan secara efisien.

\section{DAFTAR PUSTAKA}

Arikunto, 2015, Prosedur Penelitian: Suatu Pendekatan Praktik. Rineka Cipta, Jakarta.

Cahya, Laili S. 2013. Buku Anak Untuk ABK, Yogyakarta: Familia. Idrus, Muhammad. 2009, Metode Penelitian Ilmu Sosial, Jakarta: Erlangga

Deputi Bidang Perlindungan Anak (2011). Peraturan MenteriNegara Pemberdayaan Perempuan dan Perlindungan Anak Republik Indonesia, Nomor 10 Tahun 2011 tentang Kebijakan Penanganan Anak Berkebutuhan Khusus. Jakarta: Kementerian Pemberdayaan Perempuan dan Perlindungan Anak Republik Indonesia.

Gunawan, D. 2016. Modul Guru Pembelajaran SLB Tunarungu . Bandung. PPPPTK TK dan PLB.

Haliza, Nur, dkk. (2020). Pemerolehan Bahasa Anak Berkebutuhan Khusus (Tunarungu) Dalam
Memahami Bahasa. Pascasarjana Universitas Vol. 2 (1)

Indarwati, H. (2018). Pengaruh Penggunaan Pendekatan Pembelajaran Kuantum Dan Media Kartu Bergambar Terhadap KeTerampilan Membaca Nyaring Pada anak Tunarungu Vol. 2 Hal 11-21.

Indrawan, R. (2016). Metodologi Penelitian Kuantitatif, Kualitatif, dan Campuran untuk Manajemen Pembangunan, dan Pendidikan (Revisi). Bandung: PT Refika Aditama.

Kuntarto, E, dkk. (2017). Dasar-dasar Psikolinguistik Naskah Hibah Buku Nasional. Direktorat Sumber Daya Manusia Kementrian Riset, Teknologi, dan Pendidikan Tinggi.

Nirwanawati, R., Efendi, M., Kustiawan. (2015). Pengaruh Penggunaan. Media Kartu Bergambar Terhadap Peningkatan Penguasaan Kosakata Siswa Tunarungu. Jurnal Penelitian dan Pengembangan Pengembangan Pendidikan Luar Biasa 2(2): 71-76

Noviantari. 2010. Panduan Pelaksanaan Komunikasi Total Bagi Orang Dengan Kecacatan Rungu Wicara. Direktorat Rehabilitasi Sosial Orang Dengan Kecacatan Kementerian Sosial Republik Indonesia.

Ratnaningsih. (2012). Penggunaan Media Gambar Dalam Meningkatkan Pemahaman Tema Keluarga Pada Anak Tunarungu.Vol 11.

Sugiyono. 2015. Metode Penelitian Pendidikan. Bandung: ALFABETA

Sinung Restendy, Mochammad. Model Belajar Dan Komunikasi Anak Disabilitas Tunarungu Wicara Di Taman Pendidikan Al Quran Luar Biasa. Fakultas Dakwah

S, Tatang. 2015. Manajemen Pendidikan Berbasis Sekolah, Pustaka Setia, Bandung. dan Komunikasi UIN Sunan Kalijaga. Jurnal Komunika Islamika Vol. 6 (I). 